\title{
Prensa deportiva e identidad nacional: España en el Mundial de fútbol de Sudáfrica 2010
}

\author{
Manuel E. GONZÁLEZ RAMALLAL \\ Universidad de La Laguna \\ mramal@ull.es
}

Recibido: 01-10-2013

Aceptado: 04-06-2014

\begin{abstract}
Resumen:
El fútbol como vehículo de adhesión identitaria es uno de los temas que más atención ha merecido por parte de aquellos sociólogos y politólogos que se han aproximado al estudio del fenómeno futbolístico. Dando por hecho que en un contexto democrático el fútbol no ofrece una elaborada doctrina e ideología política, sino que más bien destaca por el papel que juega como elemento de nacionalización cultural, el objetivo de este artículo es analizar cómo los medios de comunicación, en este caso la prensa deportiva de Madrid y Barcelona, presentan la información en torno a la selección española en términos de adhesión identitaria a una realidad nacional española y/o catalana.

El artículo se estructura en cinco apartados. En el primero se reivindica el interés que tiene el fútbol como objeto de estudio por parte de las ciencias sociales. En el segundo se incide en la importancia del fútbol como elemento cultural, emocional y mediático que contribuye a forjar identidades nacionales superficiales y ambiguas. En el tercero nos detenemos en los cambios que ha experimentado el fútbol español en los últimos diez años en términos de clubes (con la revitalización del eje Madrid-Barcelona) y de la selección nacional (con la victoria de la selección española en los dos últimos grandes acontecimientos internacionales de selecciones nacionales). En el cuarto bloque se describen los principales resultados del estudio empírico llevado a cabo a partir del análisis de la prensa deportiva editada en Madrid y Barcelona. Finalmente, en el quinto concluimos con una reflexión en torno al binomio fútbol e identidad y al tratamiento informativo de esta realidad en el caso de la selección española.
\end{abstract}

Palabras clave: Fútbol, identidad nacional, nacionalización cultural, selección española de fútbol, prensa deportiva, análisis de discurso 


\title{
Sports newspapers and national identity: Spain in the 2010 Soccer World Cup South Africa
}

\begin{abstract}
Football and identity is one of the most important topics when sociologists and political scientists study the world of football. Taking into account that in a democratic context football doesn't offer an elaborate doctrine and political ideology, however highlights as element of cultural nationalization. The objective of this paper is to analyze how the media, in this case the sport press of Madrid and Barcelona, present the information about the Spanish national team in terms of Spanish national identity and Catalonian national identity.

The paper is divided into five sections. In the first part we defend the importance of football as object of study by social scientists. The second part emphasizes the importance of football as a cultural, emotional and media factor that helps create superficial and ambiguous national identities. In the third part we focus on the changes that Spanish football has experienced in the last ten years in terms of clubs (with the revitalization of the rivalry Madrid-Barcelona) and in terms of national team (with the victory of Spain in the last two major international events of national teams). In the fourth section we describe the main results of the empirical study that we carried out with the sports media published in Madrid and Barcelona. Finally, in the fifth part we conclude with some reflections about the relationship between football, national identity and their informative treatment in the case of the Spanish national team.
\end{abstract}

Keywords: Football, national identity, cultural nationalization, Spanish national football team, sports media, discourse analysis

\section{Referencia normalizada}

González Ramallal, M.E. (2014). "Prensa deportiva e identidad nacional: España en el Mundial de fútbol de Sudáfrica 2010". Política y Sociedad, Vol 51, Núm. 2: 337-366

Sumario: 1.jInvestigar en fútbol no es un crimen! 2.Naciones en juego, identidades en juego 3.La revitalización del eje Madrid-Barcelona y el éxito de la selección española 4.Principales resultados: la identidad contada: lo español y lo catalán 5.Recapitulando. 6. Bibliografía 
El objetivo de este texto es profundizar en torno a la construcción mediática de la identidad colectiva a través del fútbol. Las implicaciones del fútbol en términos de identidad son algunos de los temas que han merecido una mayor atención por parte de sociólogos y politólogos. Partiendo de un estudio previamente realizado sobre cómo los diarios deportivos de tirada nacional presentaron las informaciones sobre la selección española en el Mundial de fútbol de Alemania 2006 (González Rama1lal, 2008), extendemos nuestro estudio al Mundial de Sudáfrica de 2010. Los recientes triunfos de la selección española en dicho Mundial, y previamente en la Eurocopa de 2008, merecen que los discursos periodísticos procedentes de Madrid y de Barcelona en torno a la identidad nacional vuelvan a ser examinados y comparados al calor de los últimos éxitos futbolísticos. Asimismo, es necesario contextualizar este análisis sobre fútbol e identidad en el revitalizado eje futbolístico MadridBarcelona para ver cuáles son las diferencias más significativas en la forma en que se cuentan los éxitos de la selección española desde la prensa deportiva editada en Madrid (As y Marca) y desde Barcelona (El Mundo Deportivo y Sport).

Como trasfondo del texto pretendemos, además de legitimar el estudio del mundo del fútbol por parte de las ciencias sociales, examinar con mayor detalle la relación que se establece entre fútbol y política en España en términos de nación e identidad a partir de los discursos deportivos procedentes de dos entornos, Madrid y Barcelona, que representan dos formas diferentes de entender el Estado-nación español ${ }^{1}$.

\section{1. ¡Investigar en fútbol no es un crimen!}

Antes de comenzar a tratar los aspectos referidos a cómo se presenta la identidad en los diarios deportivos de tirada nacional, me gustaría dedicar aunque fueran sólo algunas líneas a justificar la pertinencia de estudiar el fenómeno futbolístico desde las ciencias sociales. Para ello empleo de manera intencionadamente dramática (y provocadora) la metáfora que preside este epígrafe: "Watching football is not a crime!", eslogan que encabeza una campaña de la Federación de Aficionados al Fútbol (Football Supporters' Federation) para reivindicar que los aficionados al fútbol (los futboleros) reciban un trato justo y dentro de la ley por parte de la policía, al igual que cualquier otro grupo social que acude a un espectáculo público, sea el

\footnotetext{
${ }^{1} \mathrm{El}$ origen de este artículo está en la presentación realizada en las Jornadas de Investigación "Fútbol, identidades sociales y discursos políticos" organizada en noviembre de 2011 por el Grupo de Estudios sobre Sociedad y Política (UCM/UNED). Mi agradecimiento a los organizadores y participantes en aquellas jornadas por hacerme pensar más en la sociología del fútbol; a Juan Salvador León Santana y Anibal Mesa López por sus valiosas críticas y sugerencias a la primera versión del texto; y a Alejandro Quiroga por facilitarme sus escritos provisionales sobre fútbol y franquismo.
} 
teatro o sea un concierto de rock $^{2}$. En este no caso no hablaremos de policías y supuestos criminales. Hablaremos de ciencia social y fútbol.

Tradicionalmente los científicos sociales han marginado el fútbol como campo de investigación y, en el peor de los casos, algunos de los que han osado abordar su estudio han podido sentirse víctimas de estigmatización académica y/o ser acusados de padecer severos síntomas de alienación. Algunas razones que explican semejante coyuntura obedecen a un conjunto de factores interrelacionados.

En primer lugar, podemos destacar la propia naturaleza del "mercado científico". Habitualmente los estudios científicos han orientado su saber hacia la resolución inmediata de problemas puntuales más que hacia el conocimiento por sí mismo, que paradójicamente suele ser el camino más eficaz para aproximarnos de manera pausada y certera a la solución de los problemas en cuestión. Como señala Dunning (2003: 18) este deseo moral y político de hacer algo, de cambiar el mundo -más que de comprenderlo- proyectaba en la mayoría de sociólogos y politólogos cierta obligación de dejar al margen aquellos aspectos considerados triviales de la vida social como el deporte, aún a pesar de que los orígenes del fenómeno deportivo se remontan a algo tan consustancialmente humano como es el juego, del cual emerge la cultura (Huizinga, 1987).

En segundo lugar, esta consideración poco seria y simplista del fútbol tiene que ver con la nefasta cuestión ideológica que hace que en ocasiones el fenómeno futbolístico sea considerado exclusivamente como constante fuente de alienación y de uso instrumental del mismo por parte del Estado capitalista y de diferentes regímenes totalitarios. Buena parte de esta visión ideologizada del deporte está fuertemente arraigada a los planteamientos que, desde el materialismo histórico, juzgan el fútbol como el opio del pueblo al servicio del Estado (Brohm, 1982) y ven en su industria un instrumento que refleja fielmente las categorías del sistema capitalista (Laguillaumie, 1978) convirtiéndose así los aficionados al fútbol en genuinos asnos como dice "La canción del pollino" (Calvo, Presas y Urrutia, 1986): "somos los que, llenamos los estadios, para poder, insultar y blasfemar, somos los que, no vamos al teatro, y somos carne de bar, y somos carne de bar [...] Somos los que, no saben no contestan, con excepción, del 1 X 2. Somos los que, no tienen biblioteca, y somos más de un millón, bastantes más de un millón".

En tercer lugar, relacionado con la cuestión ideológica, tenemos ciertos planteamientos culturales elitistas que tienden a señalar despectivamente el escaso valor económico, político y social del fútbol, al considerarlo una actividad pueril, estúpida y poco estética. Afirmaciones del estilo del literato Jorge Luis Borges señalando

${ }^{2}$ Football Supporters' Federation (www.fsf.org.uk) es una organización democrática inglesa que representa a 180.000 aficionados individuales y a miembros de las organizaciones de aficionados locales de los clubes a lo largo de toda la jerarquía futbolística doméstica. Entre otras cuestiones la FSF actúa como grupo de presión ante las autoridades gubernamentales y futbolísticas para obtener respuestas a sus demandas e inquietudes. 
que "once jugadores contra otros once corriendo detrás de una pelota no es especialmente hermoso" están en una línea argumental similar a la que estima que el fútbol no constituye un problema social digno de interés. Se infravalora el fútbol como actividad de ocio, percibiéndose más como una actividad puramente física, sin matices y sin vínculos con otro tipo de funciones "superiores", como la función económica o la estética. Ésta querencia a plantear la realidad en términos duales y contrapuestos, como si fuesen realidades absolutas existentes e inconexas: individuo y sociedad, trabajo y ocio, alma y cuerpo, lo serio y lo trivial, etc. (Corcuff, 1998; Elias, 2002), ha contribuido a marginar el fútbol como objeto de estudio desde las ciencias sociales.

Ver sólo el aspecto trivial y falto de seriedad del fútbol implica desconocer la complejidad que entrañan los fenómenos sociales totales como este, cuyo grado de profesionalización y comercialización es cada vez mayor. Ante la acusación de que el fútbol carece de función económica, el incremento del "economicismo" en el fútbol se refleja en los diferentes y detallados informes financieros de la UEFA desde la temporada 2003-2004 y de la poderosa FIFA (Villegas, 2008) desde el año $2002^{3}$. Además, como fenómeno social total que es, el fútbol se constituye como "una continuación de la política por otros medios" (Orfeo Suárez, 2000) coadyuvando a la generación de creencias, imágenes e identidades colectivas.

En cuarto lugar, fruto de la omisión del fútbol como problema social vino la desposesión, en el sentido de que, por las razones expuestas, el estudio del deporte en general y del fútbol en particular constituyó una suerte de estigma académico para aquellos que osaban aproximarse a él desde la sociología o la ciencia política, salvo que se tratase de una veleidad pasajera ${ }^{4}$. Esta renuncia desposeyó a los científicos sociales del estudio del fútbol que, en general, pasó a desarrollarse principalmente en el ámbito de investigación empírica de la educación física, que a través del fútbol encontró un nicho de mercado científico con objetivos orientados principalmente a la mejora del rendimiento físico y a la búsqueda del logro deportivo, más que a situar el estudio del fútbol y del deporte en un amplio marco social y político.

Por esta razón cuando se comenzó a abordar el estudio del fútbol desde las ciencias sociales, éste se llevó a cabo desde un plano subsidiario vinculado a otros

\footnotetext{
${ }^{3}$ Los diferentes UEFA Financial Report en

www.uefa.com/uefa/management/finance/index.html.

Los diferentes FIFA Financial Report en

www.fifa.com/aboutfifa/officialdocuments/doclists/

financialreport.html

${ }^{4}$ Un análisis bibliográfico llevado a cabo a finales de los años 70 por Lüschen y Weis (1979) sobre la evolución y el estado en ese momento de la sociología del deporte ponía de manifiesto que la sociología del deporte es uno de los dominios más olvidados y menos desarrollados de la sociología. Respecto al fútbol sólo se estudiaban algunos aspectos relativos a actos violentos cometidos por espectadores y forofos deportivos.
} 
temas de investigación considerados menos marginales, como el ocio, la educación, la religión, el género, los valores, la violencia, etc., mas no como tema convencional de investigación en sí mismo. Al margen de los estudios en el Reino Unido sobre la también estigmatizante relación entre hooliganismo y fútbol, emprendidos a principios y finales de los 70, respectivamente, por Taylor (1971) y Marsh (1978 y 1982), y durante los 80 por la Escuela de Leicester (con Norbert Elias y Eric Dunning a la cabeza), no es hasta la década de los 90 cuando a nivel internacional comienza a diversificarse el interés por estudiar el fútbol desde las ciencias sociales a partir de perspectivas, puntos de vista, metodologías y temáticas diferentes, como la relación del fútbol con los medios, la economía, la identidad, la semiología, el turismo, etc. (Giulianotti, 1997). En España se sigue un recorrido similar al internacional, sólo que con una década de retraso ${ }^{5}$.

En quinto y último lugar hemos de aludir a la tradición acientífica que el propio fútbol acoge en su seno. Como señala Williams (2009) buena parte del mundo del fútbol ha rechazado por costumbre el denominado "fútbol-ciencia" en lo que a entrenadores se refiere, orientándose las preferencias de muchos de los aficionados más puristas hacia entrenadores con experiencia, preferiblemente ex jugadores. Tipos rudos, mas con pocos conocimientos académicos de ciencia del deporte, psicología, dirección de personas, preparación deportiva, perspicacia comercial, administración científica, o conocimiento de la economía global. Es por ello que, por ejemplo, algunos de los aficionados ingleses más puristas ven poses y modales amanerados en algunos de los entrenadores considerados "científicos", muchos de los cuales no fueron ex jugadores reconocidos, como Wenger, Houllier o Eriksson. También podemos encontrar múltiples ejemplos en este sentido en otros casos distintos al inglés, donde algunos ex jugadores conocidos por más por su estilo rudo que "científico" han ejercido también como entrenadores del gusto de muchos aficionados, sin ir más lejos el ex seleccionador español, José Antonio Camacho. En los últimos tiempos en el mundo del fútbol se ha producido un significativo repliegue de las posturas acientíficas, valorándose actualmente de manera positiva la existencia en su seno de los denominados "intelectuales del fútbol" (FIFA, 2009) 6 .

En definitiva, con el paso del tiempo el deporte se significa por haberse configurado como una actividad social, cada vez más profesional y mediática, al tiempo que económica y política. La transformación del primigenio juego, como condición y naturaleza humana, en deporte como fenómeno social, no podía pasar más tiempo

\footnotetext{
${ }^{5}$ Cabe señalar el interés inicial que despiertan los desórdenes en los estadios de fútbol en los trabajos de Cancio (1990), Durán (1996) y Adán (1996) antes de que el fenómeno futbolístico comience a afianzarse en España como pertinente objeto de estudio vinculado a realidades sociales más amplias y variadas.

${ }^{6}$ En España revistas culturales como "Panenka" (www.panenka.org) o "Líbero" /www.revistalibero.com) abordan una amplitud de temas (política, arte, moda, música, religión, etc.) a través del fútbol.
} 
descuidada como campo de investigación social y política. Dentro del deporte, el fútbol es el deporte mundial por excelencia, ampliamente difundido a través de los medios de comunicación y referente de importante procesos sociales y políticos que merecen una profunda atención. Estos cambios experimentados tanto en la cancha deportiva como en la académica nos llevan a considerar el fútbol como un tema absolutamente digno de estudio teórico y empírico desde las ciencias sociales. A ello vamos.

\section{Naciones en juego, identidades en juego}

Considerando las dos grandes dimensiones del nacionalismo (Guibernau, 1996), su carácter político y su papel en la creación de la identidad, hay que señalar en la relación a la primera que en la mayoría de los casos actuales a través del deporte no se transmite una elaborada doctrina e ideología política en torno al Estado-nación y a las tensiones que se generan dentro y entre los Estados-nación. Sin embargo, el deporte sí contribuye a generar creencias, imágenes e identidades colectivas en torno a la nación, normalmente poco estructuradas a nivel político, pero con carácter doctrinario al fin y al cabo para muchos de los que siguen los acontecimientos deportivos.

Cuando hablamos de deporte y nacionalismo podemos establecer una línea divisoria más o menos evidente entre regímenes autoritarios y sistemas políticos democráticos. En el comunismo y en el fascismo existen intentos explícitos por parte de los Estados de emplear el deporte como correa de transmisión de una determinada ideología política con función integradora (González Aja, 2002; Manrique, 2011; Pujadas, 2011). El deporte se convierte en un elemento que contribuye a la construcción de la patria, ya sea como entrenamiento militar, como preparación al trabajo o como motivo de orgullo nacional. Otra cosa es que efectivamente consiga una nacionalización política. Como señala Quiroga (2013) para el período de dictadura franquista, el deporte, y en particular, el fútbol, constituyeron un medio efectivo de nacionalización española, más cultural que política (aunque nacionalización a fin de cuentas), a través del cual muchos españoles desarrollaron un vínculo sentimental (identitario) con la nación española que no conllevaba, necesariamente, una aceptación política del franquismo.

En épocas democráticas el deporte no desempeña, al menos de manera tan explícita, un papel al servicio de la nación. La actividad deportiva se ha convertido, por un lado, en una de las actividades de ocio más practicadas y en un derecho y demanda ciudadana en el marco de una sociedad deportivizada (García Ferrando y Lagardera, 1998). Por otro lado, el deporte, especialmente el fútbol, es uno de los espectáculos más seguidos a través de los medios de comunicación. Es en este contexto en el que, en momentos puntuales de éxito deportivo a nivel internacional (sobre todo Juegos Olímpicos y campeonatos mundiales), los Estados democráticos pueden "apropiarse" del deporte, instrumentalizándolo de una manera velada, implícita, aunque muy semejante a la propaganda característica de los regímenes 
políticos autoritarios. La victoria de una selección nacional o de un deportista español activa los resortes del Estado, más que con fines ideológico-políticos explícitos, con fines publicitarios al estilo de los anuncios de los Ministerios del Estado español en TV. De ahí el interés por "salir en la foto" por parte de muchos gobernantes o miembros de la Casa Real. Por supuesto, ante los fracasos deportivos, estos mecanismos de instrumentalización implícita del deporte no se activan ${ }^{7}$.

También en relación al carácter que tiene el deporte como forma de adoctrinamiento ideológico nos encontramos con la "teoría de las correspondencias" que asocia deporte y ética del trabajo (Rigauer, 1981), y con la "teoría de la reproducción", que pone al deporte al servicio del alienante sistema capitalista (Brohm, 1993). Estas teorías se tratan, en palabras del también crítico John Hargreaves (1982), de perspectivas sesgadas que le dan al deporte un sentido unívoco (y supuestamente efectivo) de reproducción de las relaciones sociales dominantes. Aun considerando ciertos efectos represores del deporte, éste también constituye una forma cultural con diversos grados de autonomía y libertad. En este equilibrio entre opresión y libertad encontramos, por ejemplo, que la incorporación progresiva del deporte a la cultura consumista genera una notable relación entre deporte e identidad nacional, con potencialidad emancipadora (Hargreaves, 1986) ${ }^{8}$.

Respecto a la dimensión identitaria del nacionalismo nos encontramos con que el deporte como fenómeno social total tiene una alta capacidad de adscripción identitaria debido a su amplio carácter cultural (los aspectos simbólicos de la identidad deportiva), emocional (las adhesiones y desafecciones que generan las pasiones deportivas) y mediático (la identidad contada y difundida a través de los medios de comunicación).

Respecto al plano cultural, dentro de la amplia gama de deportes posibles, el fútbol es sin lugar a dudas el deporte mundial por excelencia. Las razones de tal afirmación tienen que ver con la magnitud del fenómeno futbolístico en lo social, lo político, lo económico y lo mediático, que hacen que estemos ante "posiblemente el único de esos raros factores de una cultura mundial que todos entienden por encima de naciones y generaciones" (Boniface, 2006). Es tal la fuerza del fútbol que tiene la capacidad simbólica de, por un lado, hermanar y, por otro, separar a las personas en grupos de pertenencia. El fútbol vincula a personas con orígenes socioculturales

\footnotetext{
${ }^{7}$ Resulta especialmente significativo reseñar para este caso el ejemplo acontecido con el esquiador de fondo alemán nacionalizado español Johann Mühlegg. Johann compitió como español cosechando diversos éxitos deportivos durante 2001 y 2002 en una disciplina sin tradición alguna en España. Inmediatamente fue portada en los diarios deportivos y generalistas por sus victorias, y se le bautizó cariñosa y sentimentalmente como "Juanito". Fue felicitado por el Rey de España en persona y por el presidente del gobierno de la nación, a la sazón Aznar. Cuando fue acusado y sancionado por dopaje, y se le retiraron las medallas, "Juanito" volvió a ser Johann, pasó al olvido y en su biografía acusó a las autoridades deportivas españolas de dejarlo solo y no apoyarle en su defensa.

${ }^{8}$ Las citas de Hargreaves son tomadas de Dunning (2003: 131-132).
} 
muy diversos (en una suerte de populismo se dice que el fútbol une al rey y al vasallo), pero al mismo tiempo reagrupa a los individuos en simbólicos espacios de identidad "nosotros y otros". Ambas tendencias, homogeneización y diferenciación, forman parte del proceso que configura las complejas y ambiguas "fronteras de identidad" (Bauman, 2006) que genera el fútbol. El fútbol tiene la capacidad de sintetizar y concretar en una bandera, en unos colores, y en una camiseta (Gómez, 2010) y escudo portado por once futbolistas, los principales símbolos de una ciudad, región o nación en una suerte de nacionalismo difuso, que hace aparecer como algo natural la "identificación con" y la "pertenencia a" una comunidad (Billig, 1995) a través de ceremonias colectivas como los deportes, la presencia constante de la bandera nacional en la vida cotidiana (edificios públicos, plazas), la estructura informativa de los medios de comunicación (noticias nacionales y noticias del exterior), o el uso ordinario del lenguaje en frases como "la economía" (nuestra economía) o "el tiempo" (nuestro tiempo) que tienen una función creadora de comunidad nacional (Billig y Nuñez, 1998).

En segundo lugar, si algo caracteriza al nacionalismo de masas es la carga emocional que las personas invierten en la causa para defender sus símbolos y creencias. Y si algo caracteriza al deporte en general y al fútbol en particular es la inversión emocional, la pasión, que aficionados y no tan aficionados expresan ya sea en los propios terrenos de juego o a través del consumo habitual de diarios deportivos, los cuales tampoco escatiman esfuerzos en exaltar esos sentimientos. El sentido emocional del deporte (Elias, 1992; Llonch, 1996; Dunning, 2003: 39) combina perfectamente con la adhesión identitaria a unos colores y si además esta adhesión es inquebrantable, probablemente implique una manifiesta desafección hacia "otros" colores como refuerzo y vigilancia de la identidad propia, del límite entre el "nosotros" y el "ellos" (o el "a por ellos").

Finalmente, la trascendencia que tiene el fútbol como creador de identidad simbólica y emocional en comparación con otros deportes, se debe al poder de los medios de comunicación como difusores de las formas simbólicas asociadas al fútbol. La imagen pública del fútbol a nivel nacional e internacional no sólo es divulgada por los medios, sino que estos también actúan como agentes que recrean, reinterpretan y actualizan la identidad, adaptándola a los cambios percibidos. Como señala Bauman (2007: 49): "la idea de 'identidad', una 'identidad nacional' en concreto, ni se gesta ni se incuba en la experiencia humana 'de forma natural', ni emerge de la experiencia como un 'hecho vital' evidente por sí mismo". Este planteamiento problematiza la idea de identidad, pero sobre todo convierte la identidad en una tarea. La identidad ha de ser reconstruida a imagen y semejanza de la idea que se tiene sobre ella y, en este sentido, los medios de comunicación juegan un papel trascendente ya que son los encargados de contar la identidad (la identidad contada) que emerge de los rituales colectivos como el fútbol.

Los medios de comunicación interpretan el fútbol a la luz de la trama identitaria y contribuyen a forjar identidades. Teniendo en cuenta que el principio estructurador de toda competición deportiva internacional es el Estado-nación, "durante los partidos que enfrentan a equipos nacionales, el estadio se convierte en el teatro 
donde se escenifica la nación, simbolizada por la bandera y exaltada por el canto del himno. En este marco, la victoria constituye un instrumento extraordinario para transmitir una imagen de fuerza y cohesión" (Poli, 2006). La cuestión es, ¿qué sucede y cómo se articula el discurso nacionalista a través del fútbol cuando dentro de un Estado como España existen naciones sin Estado como Cataluña?

\section{La revitalización del eje Madrid-Barcelona y el éxito de la selección española}

En el fútbol español la hegemonía simbólica ha girado históricamente en torno el eje que genera el morbo (Ball, 2010) entre el Real Madrid Club de Fútbol (en adelante RMCF) y el Fútbol Club Barcelona (en adelante FCB). La rivalidad RMCF-FCB desborda los límites de la competición deportiva, situándose en el terreno de las identidades. El RMCF y el FCB dividen a la España futbolística (Relaño, 2012) y el mero hecho de declararse seguidor o simpatizante de uno de los dos clubes, expresa, aún sin intención explícita por parte de quien lo manifiesta, un cierto grado de adhesión a dos formas significativamente diferentes de entender la cuestión de la identidad nacional y, por extensión, de "sentir" la selección española. En este caso, no sólo el FCB es "más que un club" (Finestres, 2007), sino que también el RMCF es "más que un club".

Mucho se ha escrito sobre la significación sociopolítica de ambos clubes. "Ser" del RMCF o del FCB tiene connotaciones identitarias que van más allá de los deseos, explicaciones y matizaciones individuales que cada seguidor o simpatizante le quiera dar a sus filias y a sus fobias "futboleras".

Tradicionalmente se ha estudiado la asociación implícita del RMCF con el régimen franquista (Shaw, 1987) y denunciado que bajo este régimen el club madrileño debía de ser el campeón y protagonista a toda costa (Eiré, 1998). Este controvertido asunto ha sido altamente cuestionado (González Calleja, 2004), aunque se reconoce el vínculo existente entre club y régimen, pero fundamentalmente porque éste se aprovechaba del RMCF y no al revés (Santander, 1990). En un momento en que la España franquista estaba aislada a nivel internacional, el RMCF gracias a sus logros deportivos en las Copas de Europa de finales de la década de los 50, se convirtió en el mejor embajador deportivo de Franco en el exterior. A falta de otros héroes deportivos nacionales (salvo los éxitos puntuales de Bahamontes en ciclismo o de Santana en tenis) el RMCF ocupó el lugar de representación futbolística de la nación. Un lugar que le habría correspondido a la selección española de no estar huérfana de triunfos hasta la Copa de Europa de selecciones nacionales de 1964. Esta intencionada utilización del club de la capital de España por parte de la propaganda franquista lo popularizó como "el equipo del Régimen", símbolo de una España grande y próspera. Por esta razón el RMCF pudo encontrar cierto trato de favor en algunos momentos en la competición doméstica (arbitrajes, fichajes, relación con la Federación Española de Fútbol) y recibir algunas "chucherías", como las denomina Ball (2010) por parte del Régimen (elogios exaltados al RMCF de personalidades políticas franquistas, condecoraciones). Por ello, "durante el régi- 
men de Franco, y a falta de representación política adecuada, muchos aficionados, especialmente de las dos nacionalidades históricas -País Vasco y Catalunya- vieron en el Real Madrid al representante no sólo de la capital del Estado, sino del centralismo del régimen y del régimen mismo" (Santander, 1997: 95).

En buena parte del imaginario social de España permanece aún esta idea en la que el RMCF encarna a una nación centralizada y unificada en torno a la capital del Estado, a la que le cuesta reconocer otras expresiones identitarias diferentes a las que emanan de esta idea de nación. Estas manifestaciones de una identidad particular se exteriorizan a menudo en el terreno futbolístico y mediático.

En el caso del FCB tenemos un ejemplo paradigmático de sublimación de la identidad a través de una institución deportiva. Ese "más que un club" refleja las aspiraciones de buena parte del pueblo catalán de constituirse como nación, así las victorias deportivas son vividas como victorias políticas, mientras que las derrotas suponen una sentimiento de frustración por no haber podido o sabido articularse como Estado (Colomé, 1999).

Se da la circunstancia de que en los primeros años de la historia de la Liga española, el FCB no llegó a consolidarse como un club con logros deportivos importantes. Aunque ganó el primer campeonato de Liga en el año 1929, no repitió título hasta 1945 y, durante la década de los 60 y hasta 1974 no obtuvo la más importante competición doméstica. Tampoco a nivel internacional alcanzó el mayor éxito deportivo hasta la década de los noventa. Esa carencia e inconstancia de éxitos deportivos del FCB hasta prácticamente el final del franquismo impedía que el club catalán pudiese rivalizar en términos identitarios de igual a igual ante un RMCF, supuestamente protegido por el régimen. No es hasta mediados de los setenta, con el protagonismo del presidente del FCB Agustín Montal ${ }^{9}$, la llegada de Cruyff, la muerte de Franco y el regreso del presidente catalán en el exilo Josep Tarradellas (Santacana, 2006) cuando se revitaliza ese papel sociopolítico que de siempre ha tenido el FCB. Y que adquiere más fuerza a partir de los noventa, al calor de los triunfos deportivos, primero con el denominado por los medios Dream Team (por la belleza del juego desplegado) y posteriormente, ya en el siglo XXI, por el Pep Team (en honor a su entrenador Pep Guardiola).

El eje futbolístico RMCF-FCB contribuye a producir creencias e imágenes en torno a la identidad colectiva, en un contexto en el que "según las últimas encuestas [...] los imaginarios español y catalán se están distanciando a marchas forzadas, alentados por una clase política incapaz de gestionarlos y unos medios de comunicación más violentos que las armas" (Palencia, 2011).

${ }^{9}$ Montal, presidente del FCB desde 1969 a 1977, fue un gran defensor del catalanismo, recuperando y creando para el FCB algunos de sus principales símbolos (por ejemplo el actual y conocido himno "Cant del Barça"). También se opuso abiertamente, en los estertores del franquismo, al centralismo futbolístico de la Federación Española de Fútbol. 
Si nos ceñimos exclusivamente al tradicional protagonismo informativo dado por los medios a estos dos clubes (Bonaut, 2004; González Ramallal, 2004a), representativos uno del Estado-nación España y otro de la nación sin Estado Cataluña, hay que señalar que entrada la década de los noventa tal protagonismo parecía tender a diluirse. Junto a los éxitos deportivos del RMCF y FCB, otros clubes españoles alcanzan logros deportivos domésticos y/o tienen presencia destaca en competiciones europeas (Valencia, Atlético de Madrid, Zaragoza, Espanyol, Deportivo, Celta, Alavés, Mallorca), pasando a cobrar cierta relevancia en los medios. Parecía estarse "proyectando en el espacio futbolístico el mismo proceso de modificación de las antiguas relaciones entre el centro y la periferia que el que se ha venido produciendo en la sociedad española por la existencia de un desarrollo económico más disperso que el de antaño y por la creciente relevancia de las capitales autonómicas de gran tamaño [...] que desdibuja la estructura radial, y se muestra más ajustado al potencial económico y comercial de las distintas regiones españolas y a los trazados apuntados por las nuevas redes de telecomunicación y transportes" (Llopis, 2009: 54).

Este escenario advertido en la década de los noventa parecía que con el tiempo iba a debilitar el protagonismo del RMCF y del FCB y, por extensión, a desarrollar un marco de identidades más plural expresado simbólicamente a través el fútbol. Sin embargo, a medida que el cambio de siglo avanza la situación se ha revertido a niveles similares a tiempos pretéritos y, si cabe, con más fuerza aún. El eje futbolístico-identitario Madrid-Barcelona ha cobrado una fuerza inusitada que responde a diversos motivos.

En primer lugar, se ha incrementado la presencia mediática de estos dos clubes por centrismo (el centro de la atención informativa recae de manera significada sobre RMCF y FCB) y superabundancia informativa (efecto acumulativo en los diferentes medios de noticias sobre RMCF y FCB). Ambas instituciones deportivas gozan de un seguimiento diario que abarca las 24 horas del día en los casos de Real Madrid Televisión y Barça Televisión. Como ya hemos estudiado en su momento (González Ramallal, 2004b) a parte de la gran presencia que el club madrileño y el barcelonés tienen en la prensa deportiva y generalista y en los espacios deportivos de radio y televisión, hay que señalar como novedad el seguimiento que reciben por parte de cadenas específicamente deportivas de radio (Radio Marca) y televisión (Marca TV), así como por los nuevos programas deportivos surgidos al calor de la TDT como Futboleros o Punto Pelota. Estas cadenas de televisión, a falta de los derechos de retransmisión de los partidos del RMCF y del FCB, han de llenar sus horas de programación deportiva con tertulias, debates, en los que, el leitmotiv principal son contenidos donde se libra la enconada "eterna batalla" entre RMCFFCB. Los éxitos de un club, no son explicados si no es a partir de los fracasos del otro. 
Buena parte de esa "salsa rosa" futbolística ${ }^{10}$ se dirime con periodistas y pseudoperiodistas que no esconden su afinidad por uno u otro club. De hecho, es precisamente su manifiesta identificación con uno de ellos lo que en ocasiones centra el espectáculo mediático en torno al RMCF y al FCB. Se ha perdido buena parte de la asepsia informativa y profesionalismo que caracterizaba el periodismo de antaño cuando se trataba de abordar cuestiones futbolísticas domésticas. Hoy existe una clara división, eje periodístico entre Madrid (la caverna mediática, la central lechera) y Barcelona (prensa afín, medios al servicio del club), en lo que en ocasiones se ha denominado periodismo deportivo de trincheras.

En segundo lugar, otra circunstancia a tener en cuenta en la revitalización del eje Madrid-Barcelona es la difusión del fenómeno futbolístico a través de las nuevas tecnologías, especialmente entre los más jóvenes, que encuentran en ellas un instrumento facilitador para la identificación con uno u otro club, sean o no sean fieles aficionados al fútbol ${ }^{11}$. En este campo también el RMCF y el FCB se llevan el protagonismo a nivel mundial, al ser líderes de las redes sociales y de contenido en el ámbito de las instituciones deportivas con más de 22 y 25 millones de seguidores, respectivamente, entre Facebook y Twitter ${ }^{12}$.

Otro factor que ha agudizado la distancia entre el RMCF y el FCB como los dos ejes de un mismo polo, y el resto de los equipos tiene que ver con la aguda y creciente brecha económica entre los clubs en la competición doméstica. El RMCF contaba para la temporada 2011-2012 con un presupuesto en torno a los 510 millones, el FCB de 461 millones. El Málaga, tercer presupuesto más alta, tenía 150 millones tras la compra del club por un jeque qatarí. El resto presenta cantidades significativamente inferiores, y 11 de 20 clubes no alcanzan los 50 millones de presupuesto. Esta desigualdad presupuestaria tiene normalmente consecuencias deportivas al limitar a la mayoría de los clubes, salvo RMCF y FCB, las posibilidades de obtener logros deportivos domésticos.

Desde el año 2004 la Liga española ha sido ganada por únicamente por el RMCF o FCB en lo que se percibe como un proceso de "escocificación" de la máxima

${ }^{10}$ Denominación coloquial de programas basados en la crónica social, dicho de otro modo programas centrados en rumores, noticias, cotilleos, y encuentros y desencuentros, entre famosos. Toma esa denominación del extinto programa que emitía la cadena Telecinco "Salsa Rosa", género hoy ocupado por "Sálvame".

${ }^{11}$ Como pregunta en el marco de una conversación cotidiana; como ritual de sociabilidad característico de los niños cuando se disponen a jugar en el parque, sobrevuela la cuestión: “¿eres del Madrid o del Barça?”, como si no existiesen (al menos no se suelen contemplar) otras opciones.

${ }^{12}$ Véase

http://www.marca.com/2011/10/17/futbol/1318849516.html?a=2dc59ae4c30b0ece3eacd $859 f 4 b 36194 d \& t=1318859103$ 
competición doméstica española ${ }^{13}$. Esto imposibilita a la mayoría de los clubes obtener ingresos adicionales por participar en la máxima competición de clubes europea, la Champions League. Este proceso lo apreciamos también a nivel europeo en las principales competiciones nacionales de clubes, pero se agrava especialmente en el caso español al existir en comparación con aquellas (Premier League inglesa, Serie A italiana, Bundesliga alemana, o Ligue 1 francesa) una mayor desigualdad en el reparto de ingresos por derechos de televisión, que impide crecer a los clubes más humildes (Anglés y Gay de Liébana, 2011) y competir en igualdad de condiciones con los más poderosos, especialmente RMCF y FCB, que experimentan cada vez con más intensidad el denominado "efecto Mateo"14.

Es cierto que tradicionalmente tanto RMCF como FCB han sido clubes con éxito deportivo relativamente frecuente en comparación con otros clubes españoles y que también han tenido una mayor presencia demográfica, social y mediática (municipios con mayor volumen de población, mayor número de socios y simpatizantes, peñas y asistentes al estadio, mayores audiencias). Si a estas circunstancias le añadimos las que tienen que ver con el mayor seguimiento mediático y la creciente brecha económica que se traduce en menores logros deportivos para el resto de clubes españoles ${ }^{15}$, encontramos algunas de las claves de la revitalización del morboso eje mediático Madrid-Barcelona.

Este debate dual en términos futbolístico-identitarios hay que conectarlo con el protagonismo y éxito deportivo alcanzado por la selección española, primero en la Eurocopa 2008 y posteriormente en el Mundial $2010^{16}$. En pocos años se pasó de un cierto desapego identitario hacia la selección española (que abría los debates en torno a una supuesta anorexia patriótica por las preferencias de adhesión identitaria hacia los clubes de fútbol más que hacia la selección nacional) ${ }^{17}$, a la supuesta explosión de un sentimiento nacionalista tejido en torno a los éxitos de la selección

\footnotetext{
${ }^{13}$ Se habla de "escocificación" para hacer referencia a que desde 1986 la Liga Escocesa sólo la ganan o el Celtic o el Rangers. Es cierto que durante otras épocas también existió una hegemonía en España de dos únicos clubes, RMCF y FCB (de 1957 a 1965 y de 1985 a 1995). Pero si algo llama la atención respecto a épocas pasadas es la abismal diferencia de puntos que normalmente uno de los dos clubes, o los dos, logran frente a sus rivales en la clasificación final.

${ }^{14}$ Acumulación de bienes, riqueza y/o fama por parte de aquellos que más gozan de ello. Como dice la parábola de Mateo del Nuevo Testamento: "Al que más tiene más se le dará, y al que menos tiene, se le quitará para dárselo al que más tiene".

${ }^{15}$ Para la gran mayoría de los clubes españoles salvarse del descenso, clasificarse para una fase previa de Champions League o jugar unas semifinales de Copa del Rey (tres ejemplos de éxito deportivo sin derecho al protagonismo que da obtener un título) supone “arañar" algo de espacio y tiempo en los medios de comunicación.

${ }^{16} \mathrm{Y}$ en la Eurocopa 2012, que en el momento en que se escribió la primera versión de este artículo todavía no se había logrado.

${ }^{17}$ Ver Llopis, 2006.
} 
española (González Blasco, 2008). Todo ello en un contexto ambivalente marcado por la mayor permisividad respecto a la existencia de identidades plurales expresadas a través de las selecciones autonómicas, nacionales para algunos.

Este nuevo escenario nos remite a la cuestión de ¿cuál es el significado de la selección española en términos de atracción identitaria en un marco mediatizado por el eje Madrid-Barcelona (dos formas de entender España) y por la aceptación y el reconocimiento de identidades plurales?

Todos estos cambios hacia el pluralismo identitario y hacia la revitalización del eje Madrid-Barcelona se gestaron paralelamente al desarrollo de la Ley del Deporte de 1990 y a la denominada Ley Bosman de ese mismo año. Por un lado, la Ley del Deporte obligaba a la conversión de la mayoría de los clubes españoles en Sociedades Anónimas Deportivas ${ }^{18}$, lo que implicaba un reconocimiento explícito de la artificialidad de los sentimientos en el fútbol, al transformarse los clubes en sociedades mercantiles, en un negocio, en una empresa más, si bien con ciertas características especiales que les convierten en los que podemos denominar empresas de sentimientos y de solidaridad identitaria. Por otro lado, la Ley Bosman levantaba las restricciones existentes para proteger a los jugadores nacionales, que limitaban el número de jugadores extranjeros en las plantillas de los clubes nacionales. Las plantillas de los clubes se internacionalizan, y en esencia parece un contrasentido hablar, por ejemplo, de equipos ingleses, españoles, rusos, etc., sin, respectivamente, ingleses, españoles o rusos en sus filas.

La globalización en términos de apertura del mercado futbolístico y la organización más racional (menos sentimental) del fútbol en Sociedades Anónimas Deportivas generan en el plano futbolístico un marco identitario cada vez más complejo, paradójico y difuso. La identidad necesita reconstruirse, renovarse y adaptarse constantemente bajo las nuevas circunstancias, se precisan elementos identitarios distintivos, más locales que globales. La identidad se convierte así, en palabras de Bauman (2006), en una tarea. Aficionados, periodistas y opinión pública en general siguen hablando de clubes ingleses, españoles, rusos, etc., pesando aún más el elemento de armonía etnoterritorial, ya sea ésta local, regional o nacional (nuestro equipo, "el de aquí"), que la verdadera composición multiétnica del club. Ni la conversión de los clubes en Sociedades Anónimas Deportivas ni la Ley Bosman han afectado a los aficionados españoles, que siguen identificándose básicamente con un equipo de fútbol por su significación territorial con el lugar y por la capacidad de simbolización que los clubes tienen debido a los vínculos que establecen con su entorno geográfico (Llopis, 2006).

En el caso que nos ocupa nos vamos a encontrar con un fenómeno de generación y regeneración de la identidad colectiva mediante el fútbol que se difunde y propaga

${ }^{18}$ RMCF y FCB, junto al Athletic Club de Bilbao y Club Atlético Osasuna, quedaron excluidos de este obligado trámite por presentar beneficios económicos en las tres últimas temporadas a la aprobación de la Ley del Deporte. 
a través de los medios de comunicación. Cuando la selección española, como representante del Estado-nación España, compite en eventos futbolísticos internacionales la construcción de la identidad nacional se nos presenta ambigua, confusa y problemática en función de si nos la cuenta la prensa deportiva editada en Madrid o lo hace la editada en Barcelona.

\section{Principales resultados: La identidad contada: lo español y lo catalán}

En este apartado vamos a destacar los principales resultados obtenidos del análisis de la prensa deportiva editada en Madrid y en Barcelona. Hay que señalar que en este artículo partimos de las conclusiones obtenidas de un estudio previo relativo a cómo se contó la identidad en el Mundial de fútbol de Alemania 2006 a partir de las informaciones periodísticas en torno a la selección española (González Ramallal, 2008). En dicho estudio apreciábamos que más que en la estructura informativa y protagonistas/temas tratados en la prensa deportiva editada en Madrid (Marca y As) y Barcelona (El Mundo Deportivo y Sport), las principales diferencias entre uno y otro ámbito de edición estaban en la forma de tratar los contenidos (positiva o negativamente) y en el grado de atención prestado al evento deportivo mundialista (en forma de mayor o menor espacio dedicado a la participación de la selección española en el Mundial). Mientras en el Marca y el $A s$ la línea informativa en torno a la identidad era homogénea y centrada en un significado unívoco ("todos" somos la selección) y triunfal (somos los mejores -hasta que perdemos-) de la selección española, en El Mundo Deportivo y en Sport la realidad presentada en torno a la selección -además de ocupar menos espacio informativo- estaba marcada por la confrontación RMCF-FCB, presentaba mayor distanciamiento respecto a ciertos estereotipos de la identidad española, y era más crítica al analizar las posibilidades de triunfo español en el campeonato.

En el 2006 algunas de las diferencias más acusadas de los diarios deportivos barceloneses con respecto a los madrileños fueron la demanda por parte de aquellos de un líder de la selección más acorde a su entorno (Puyol, Xavi o Iniesta versus Raúl) y la menor insistencia en algunos de los elementos simbólicos más típicos con los que se presentaba visualmente a los aficionados españoles desde Madrid (toros, monteras, capotes, trajes flamencos de «faralaes», gorros cordobeses, tricornios de la Guardia Civil). En el momento de la eliminación de España en el Mundial 2006 en octavos de final contra Francia la prensa deportiva editada en Madrid apeló al histórico fatalismo de la selección (Quiroga, 2013), mientras que la de Barcelona buscó las causas del fracaso en aspectos más centrados en la poca efectividad del juego.

Teniendo en consideración estos resultados válidos para el Mundial 2006, extendemos este estudio sobre la identidad contada por los diarios deportivos al Mundial de Sudáfrica de 2010. La pertinencia de tal actualización radica en dos cambios que han implicado transformaciones significativas en los discursos sobre fútbol e iden- 
tidad tomando como referencia la selección española y el eje identitario MadridBarcelona.

Por un lado, tenemos que la selección española se ha convertido a partir del 2008 en una selección de éxito europeo y mundial con las victorias en la Eurocopa de 2008 y en el Mundial de $2010^{19}$. Por otro lado, dicho triunfo se fraguó con una importante participación de jugadores del FCB (siete de once jugadores en el equipo titular de la final; cuatro jugadores del FCB en el equipo ideal del Mundial). De hecho, según se iba desatando en los medios y en las calles la pasión por la selección española ${ }^{20}$, mayor número de jugadores del FCB pasaban a ocupar un especial protagonismo en la selección española (goles decisivos de Villa, Puyol, Iniesta; participación creciente en el equipo de Pedro), con permiso de Casillas, Sergio Ramos y Xabi Alonso, únicos representantes del RMCF con significativos minutos de juego.

Éxito y "barcelonismo" en la selección española. ¿Cómo se articula esta realidad en términos discursivos desde la prensa deportiva de Madrid y Barcelona? ¿Cómo conjugan los medios deportivos la ambigua cuestión de la demarcación de sentimientos e identidad entre dos clubes que representan dos formas diferentes de entender el Estado-nación? El éxito deportivo español logrado con mayoría de jugadores catalanes del FCB, ¿difumina o acentúa las fronteras entre España y Cataluña? Dicho de otro modo, el triunfo mundialista, ¿refuerza desde el punto de vista simbólico la uniformidad identitaria en torno al Estado-nación o, por el contrario, alimenta las particularidades identitarias de una nación sin Estado debido al protagonismo catalán en la selección española (la Constitución Española de 1978 reconoce a España como un Estado con diversas nacionalidades y regiones)?

Partimos de la hipótesis de que el éxito deportivo logrado en el Mundial 2010 con una base mayoritaria de jugadores del FCB en el equipo titular habitual ${ }^{21}$, no sólo no supone cambios significativos en la forma de presentar la identidad española desde Madrid y Barcelona, sino que en el caso de la prensa deportiva editada en Madrid se refuerza en un contexto de éxito deportivo la idea de la homogeneidad y unidad del Estado-nación, sin incidir en exceso en la pluralidad identitaria. Por su

\footnotetext{
${ }^{19}$ Desde el mes de julio de 2008 la selección española ocupa el primer puesto en la Clasificación Mundial FIFA de selecciones. Ver

http://es.fifa.com/worldranking/rankingtable/index.html

${ }^{20}$ Incluso en lugares tan poco habituales como Barcelona, Bilbao o Pamplona, circunstancia destacada en algunas portadas de los diarios deportivos editados en Madrid. Y donde, en algún caso, existieron reyertas más o menos graves entre aficionados.

${ }^{21}$ Equipo habitual (en base al número de minutos jugados a lo largo del Mundial 2010): Iker Casillas; Sergio Ramos, Puyol, Piqué, Capdevilla; Xabi Alonso, Busquets, Xavi; Iniesta, Villa y Pedro. De los 11 jugadores 7 son del FCB (incluimos a Villa que ya se sabía que la temporada 2010-2011 iba a jugar en el club catalán), 3 del RMCF y 1 del Villareal. De los 7 jugadores del FCB, 4 son catalanes. Los otros tres aun no siéndolo catalanes por nacimiento (ius soli), lo serían por su filiación deportiva al FCB (ius sanguinis).
} 
parte, en el caso de los diarios editados en Barcelona se intensifican los argumentos capitalizadores del triunfo de la selección española en el ámbito propio de una nación sin Estado, presentando "lo catalán" (a través del FCB) como algo excepcionalmente diferente y triunfal.

Para analizar la deriva simbólica en torno a la identidad en relación al fútbol de selecciones nacionales hemos centrado nuestro análisis en los cuatro diarios deportivos de tirada nacional: Marca y As, como ilustrativos de la presentación de una identidad española homogénea focalizada en "lo español", y El Mundo Deportivo y Sport, como ejemplo de la presentación de una identidad singularizada en "lo catalán",22.

De los cuatro diarios tomamos como referente de análisis las informaciones sobre el Mundial 2010 contenidas en sus portadas desde el 11 de junio de 2010, fecha del inicio del Mundial, hasta el 13 de julio, 2 días después de la finalización del Mundial, con el objeto de incluir también como se contaron las celebraciones por la victoria obtenida. El hecho de centrarnos exclusivamente en las portadas es que en ellas encontramos sintetizada la información escrita y visual que se pormenoriza en el interior del diario. La portada es el escaparate de un diario, supone una llamada de atención al lector y un elemento fundamental para atraer al público. Además comparativamente con los diarios de información general, los diarios deportivos destacan por sus coloridas portadas de gran tamaño cargadas de alto valor simbólico (Marrone, 2009). Las portadas nos van a permitir concentrarnos en el análisis de los elementos más significativos de la identidad tal y como la cuentan los medios.

Siguiendo la metodología empleada en González Ramallal (2004b y 2008), se analizaron 132 portadas ( 33 de cada diario) de las cuales se registraron las informaciones escritas y visuales contenidas en ellas correspondientes al Mundial 2010. Se consideró lo escrito (en titulares, antetitulares y subtitulares) y lo visual (en imágenes y gráficos), así como su magnitud (tamaño de letra e imágenes). Registramos también los protagonistas de las informaciones, explicitando su pertenencia (si fuese el caso) a una selección nacional, pero también a un determinado club. Una vez recopilados los datos empíricos, estos se computaron y se interpretaron a la luz de la cuestión identitaria, del eje Madrid-Barcelona y de la selección española, mediante el análisis sociológico del discurso escrito y visual, cuya coherencia global la encontramos expresada en titulares y fotografías de portada. Contemplamos el discurso como información, como ideología y como producto social (Martín Criado, 1991; De Miguel, 2003; Pantoja, 2007; Ruíz, 2009).

Entrando ya en los aspectos referentes a los principales resultados de investigación hay que señalar que la participación de la selección española en el Mundial de Sudáfrica es objeto de un mayor seguimiento por parte de la prensa deportiva editada en Madrid que en la de Barcelona, al menos en los momentos iniciales del

${ }^{22}$ Sobre la afinidad entre RMCF y Marca y As, por un lado, y FCB, y El Mundo Deportivo y Sport, por otro, ver Marrone (2009). 
campeonato. Las competiciones oficiales de selecciones nacionales no pueden ser desempeñadas más que por selecciones representantes de un Estado-nación y, en este sentido, hay una primera evidencia que es el mayor distanciamiento informativo vinculado a la representación deportiva española por parte de los diarios deportivos editados en Barcelona frente a los de Madrid. Estos presentan un mayor seguimiento de informaciones mundialistas en portada referidas a la selección española: $62 \%$ de informaciones vinculadas a España en los casos de As y Marca; 37\% en los de El Mundo Deportivo y Sport.

Marca y $A s$ integran en su portada noticias mundialistas en torno a la selección española de manera regular y amplia en extensión. Los diarios deportivos editados en Barcelona presentan normalmente la información mundialista en sendos cuadernillos interiores, reservando la portada para noticias más "domésticas", normalmente referidas al FCB. Sin embargo, conforme España va obteniendo resultados exitosos en el Mundial, con un elevado protagonismo de los jugadores del FCB, las portadas catalanas comienzan a ser copadas por el mundial, invirtiéndose los términos iniciales advertidos al inicio del campeonato.

Como muestra las portadas del día en que comenzó el Mundial de Sudáfrica en los diarios madrileños: (nosotros) "Empezamos a soñar. La roja aterriza hoy en Sudáfrica", con una gran fotografía de la Copa del Mundo en Marca (11/06/2010), y "iA por ellos, Oé! España llega hoy a Johannesburgo" con foto a portada completa de Iker Casillas (RMCF) en As (11/06/2010). Más allá del tono emotivo empleado, resulta significativo comparar las diferencias de estas portadas con las de $E l$ Mundo Deportivo y Sport. En el primero apenas hay un recuadro en el margen inferior derecho con referencia al inicio de un Mundial, sin alusiones a la llegada de España a Johannesburgo. La noticia e imágenes que copan la práctica totalidad de la portada tienen que ver con las elecciones a la presidencia del FCB (El Mundo Deportivo, 11/06/2010). En el segundo, en la portada del cuadernillo mundialista aparece: (ellos) "Quieren esta Copa" con fotografía de Puyol, Xavi e Iniesta y una gran Copa del Mundo detrás. Este desapego inicial hacia la participación de la selección española en el Mundial por parte de los diarios deportivos editados en Barcelona contrasta con los editados en Madrid. En estos, también resulta especialmente llamativo que la importancia que se le da a España en el Mundial implica a noticias de portada con otros deportistas de disciplinas diferentes al fútbol. Este "mundialismo" imperante se aprecia en varias portadas, donde las victorias del NBA Pau Gasol, consiguiendo su segundo anillo de campeón, y de Nadal en consiguiendo su segundo Wimbledon, están matizadas y mediadas por la selección de fútbol: "Si él puede (Gasol), vosotros (España) también" (Marca, 19/06/2010); "Nadal ya ha ganado "su Mundial"” (As, 4/07/2010); "Ayer Rafa, el domingo la Roja" (Marca, 5/07/2010).

No sólo en lo que se refiere a la atención informativa prestada al Mundial encontramos las primeras diferencias entre Madrid y Barcelona, también si nos fijamos en los protagonistas de las informaciones de portada (ver Tabla 1) apreciamos distintos puntos focales para captar el interés de los lectores. 
La referencia explícita a España, a la selección española, es casi obligada en todos los casos analizados debido a su participación mundialista como representante del Estado-nación España en el cual se integran los jugadores del FCB. Sin embargo, como cabía esperar, el protagonismo de España (la selección) es mayor para el caso de los diarios deportivos editados en Madrid que para los de Barcelona, 18,4 \% y $11,9 \%$ respectivamente. Al margen de los jugadores, también encontramos diferencias en la atención informativa que se le presta al seleccionador Del Bosque (ex jugador y ex entrenador del RMCF) y a los aficionados españoles en los diarios en función de su lugar de edición. Los aficionados, los seguidores, el pueblo español, normalmente presentados por los diarios deportivos editados en Madrid como baluartes de un nacionalismo español folklórico y estereotipado, apenas son significativos para los diarios deportivos editados en Barcelona (6\% en Madrid frente al $0,8 \%$ en Barcelona).

Tabla 1. Actores principales y grado de protagonismo en las portadas (texto e imagen).

Total, prensa deportiva de Madrid y prensa deportiva de Barcelona.

\begin{tabular}{|l|c|c|c|}
\hline $\begin{array}{c}\text { Actores } \\
\text { protagonistas }\end{array}$ & $\begin{array}{c}\text { Protagonismo } \\
\text { total }\end{array}$ & $\begin{array}{c}\text { Protagonismo en } \\
\text { prensa } \\
\text { editada en Madrid }\end{array}$ & $\begin{array}{c}\text { Protagonismo en } \\
\text { prensa } \\
\text { editada en Barcelona }\end{array}$ \\
\hline España & $15,7 \%$ & $18,4 \%$ & $11,9 \%$ \\
\hline Villa & $7,9 \%$ & $6,7 \%$ & $8,8 \%$ \\
\hline Del Bosque & $6,9 \%$ & $8,4 \%$ & $5 \%$ \\
\hline Iniesta & $5,2 \%$ & $3,4 \%$ & $6,9 \%$ \\
\hline Messi & $4,5 \%$ & $0,5 \%$ & $8,8 \%$ \\
\hline Xavi & $4 \%$ & $1,5 \%$ & $4,7 \%$ \\
\hline Aficionados & $3,6 \%$ & $6,0 \%$ & $0,8 \%$ \\
\hline Ronaldo & $3,5 \%$ & $4,2 \%$ & $2,8 \%$ \\
\hline Puyol & $3,1 \%$ & $0,7 \%$ & $5,5 \%$ \\
\hline F. Torres & $2,9 \%$ & $3,7 \%$ & $1,9 \%$ \\
\hline Casillas & $1,4 \%$ & $2 \%$ & $0,8 \%$ \\
\hline Maradona & $1,4 \%$ & $1,2 \%$ & $1,9 \%$ \\
\hline Cesc & $1,3 \%$ & $0,7 \%$ & $1,9 \%$ \\
\hline Barcelona & $1,2 \%$ & No aparece & $2,5 \%$ \\
\hline Kaká & $1 \%$ & $2 \%$ & No aparece \\
\hline Pulpo Paul & $0,8 \%$ & $1 \%$ & $0,5 \%$ \\
\hline Piqué & $0,8 \%$ & No aparece & $1,6 \%$ \\
\hline Higuaín & $0,8 \%$ & $0,8 \%$ & $0,8 \%$ \\
\hline Fin & & &
\end{tabular}

Fuente: elaboración propia.

Si analizamos el protagonismo de los jugadores en portada apreciamos importantes contrastes y una alta orientación a focalizar la atención ya sea en jugadores del RMCF (Marca y As), ya sea del FCB (El Mundo Deportivo y Sport). Este hecho 
deriva de la fuerza resultante del revitalizado eje informativo Madrid-Barcelona que hace que los diarios presenten a los jugadores más como emblemas de uno u otro club, que como participantes de una misma selección nacional. Pero esto también tiene que ver con un proceso, que detallaremos posteriormente, que es el tratamiento por parte de los diarios deportivos catalanes del éxito de la selección española en términos particulares, centrándose en los jugadores del FCB. Estas afirmaciones son válidas salvo para el caso de Villa, jugador sobre el que parece existir cierto consenso en el grado de atención informativa desde Madrid y Barcelona, por razones que tienen que ver, para el caso de El Mundo Deportivo y Sport, con el hecho de ser próximo jugador del FCB para la temporada 2012-2013 y, para el caso de Marca y $A s$, por ser un jugador con un cierto perfil que podemos "español", es decir al tratarse un jugador de origen asturiano, no criado futbolísticamente en La Masía ${ }^{23}$ y que, además, en su momento fue objeto de interés deportivo por parte del RMCF. Para todos los demás jugadores prima el carácter protagónico de pertenencia a uno u otro de los clubes que marcan el eje RMCF-FCB. Esta cuestión se hace extensiva al resto de jugadores del Mundial que, sin pertenecer a uno u otro club, son objeto de atención periodística por el hecho de estar vinculados al RMCF (Cristiano Ronaldo, Higuaín y, aunque no aparecen en la Tabla 1, Casillas y Kaká) en el caso de Marca y As, o al FCB (Messi, Iniesta, Puyol y Xavi) en el caso de El Mundo Deportivo y Sport.

En resumen, tanto en lo que respecta a la cobertura informativa dada a la selección española como a los protagonistas de las informaciones de portada, registramos una significativa desigualdad entre los diarios deportivos editados en Madrid y Barcelona bastante semejante a los resultados obtenidos al analizar el Mundial 2006 (González Ramallal, 2008). Sin embargo, a diferencia del 2006, en el 2010 la selección española va a obtener un éxito deportivo sin precedentes que va a afectar a la cuestión del tratamiento de la identidad por parte de la prensa deportiva de Madrid y Barcelona. Es interesante resaltar este hecho porque vamos a ver como a medida que la selección española va avanzando en el Mundial y comienzan a ser reconocidos sus méritos deportivos a nivel internacional, algunas cuestiones identitarias se refuerzan y otras se reconfiguran desde uno y otro ámbito de influencia periodística, reflejo de lo que supone la consideración de la identidad como tarea y como proceso.

La identidad no es algo estático, cambia conforme cambian las circunstancias, en este caso, vinculadas a un acontecimiento deportivo transmisor de símbolos y valores identitarios. Para ver esta cuestión procesual a través de la identidad contada consideraremos tres ejemplos significativos. En primer lugar, veremos un caso referido a la construcción de las fronteras de la identidad propias (locales, regionales o nacionales) a través de la instrumentalización de elementos internacionales. En segundo lugar, señalaremos como las fronteras que delimitan el nosotros-ellos son

\footnotetext{
${ }^{23}$ Academia donde se forman las categorías inferiores del FCB.
} 
altamente volubles y se modifican en función de las circunstancias inmediatas. Y en tercer lugar, analizaremos el proceso de refuerzo, por un lado, y reconstrucción (relectura) de la identidad en términos particulares, por otro, que se produce desde el ámbito del periodismo deportivo de Madrid y Barcelona, respectivamente.

Al calor de la revitalización de la disputa informativa RMCF-FCB hemos visto como desde Madrid y Barcelona existen diferencias protagónicas de los jugadores de la selección en función de su pertenencia a uno u otro club. Esta afirmación, válida para los jugadores seleccionables por España, es válida también para aquellos que no pueden formar parte de ella, en un claro ejemplo de construcción y delimitación de las fronteras de la identidad a través del uso deliberado e interesado por parte de la prensa deportiva de jugadores no españoles que conforman parte de otros seleccionados mundialistas.

Para esta tarea no vale cualquier jugador, sino que, además de pertenecer al RMCF o al FCB, ha de ser un jugador de reconocido prestigio internacional (por ejemplo mundialistas en Sudáfrica del RMCF como Van der Vaart o Pepe, y del FCB como Abidal o Márquez no cobran verdadera relevancia). En el caso que nos ocupa vemos como As y Marca acogen como "estrella invitada" a Cristiano Ronaldo (fotografía a portada casi completa de Cristiano Ronaldo en Marca 14/06/2010, y en $A s$ 15/06/2010, donde afirma en entrevista "Quiero ser el mejor jugador del Mundial"), mientras que El Mundo Deportivo y Sport lo hacen con Messi ("Exhibición de Messi" en El Mundo Deportivo 13/06/2010; "La hora de Messi", "Capitán Messi, a octavos" en Sport 12/06/2010 y 23/06/2010, respectivamente). Este fenómeno de acogida que, permítaseme la frase, otorga a los elegidos una doble nacionalidad al servicio de la prensa deportiva editada en Madrid y Barcelona, contribuye también a crear un "colchón de seguridad informativa" si se diese el caso de, por ejemplo, una pronta eliminación de la selección española y hubiese entonces que optar por seguir el Mundial "siendo" (sintiendo, animando) de Portugal o Argentina, con el objeto de mantener viva la llama de la emoción mediante un juego de alianzas y adhesiones identitarias con uno $\mathrm{u}$ otro jugador, que de este modo pasan a convertirse en referentes informativos de alguno de los dos polos desde donde nos cuentan la identidad a través del fútbol.

Esta instrumentalización de jugadores del RMCF y del FCB actúa también como refuerzo del eje informativo Madrid-Barcelona, cuestión siempre presente en mayor o menor medida en el ámbito de la identidad contada. Por ejemplo, el diario $A s$ en su portada del 28/06/2010 traslada al plano mundialista los affaires futbolísticos domésticos, al titular a portada casi completa "Villarato sin fronteras" 24 los fallos arbitrales acaecidos en el partido de octavos de final entre Alemania e Inglaterra y compararlos con los agravios arbitrales sufridos por el RMCF a favor del FCB en el

${ }^{24}$ El "villarato" es un término acuñado por el director del $A s$, Alfredo Relaño, para designar una supuesta conjura dirigida por el presidente de la Federación Española de Fútbol, José María Villar, para otorgar favores, principalmente arbitrales, al FCB. 
campeonato doméstico. También funciona a favor del eje, el "pique" con Cristiano Ronaldo por parte del El Mundo Deportivo y Sport a las puertas del enfrentamiento España-Portugal ("Cristiano se bloquea con Messi" en El Mundo Deportivo 27/06/2010; "Apuntan a Ronaldo" y "Villa contra Ronaldo" en Sport 27/06/2010 y 29/06/2010, respectivamente).

Precisamente a la luz de este encuentro entre la selección portuguesa y la española encontramos un segundo ejemplo que pone claramente de manifiesto la volubilidad inherente a la construcción de las fronteras identitarias nosotros-ellos, proceso altamente paradójico. Como señalábamos en el anterior ejemplo Cristiano Ronaldo fue "acogido" y aliado durante un tiempo en el "nosotros" de la prensa deportiva editada en Madrid, por su filiación con el RMCF. Mas en el momento en que la selección lusa ha de enfrentarse a la española, se genera un inmediato y circunstancial desplazamiento en repliegue de los hitos fronterizos, en lo que representa un paradójico proceso de reconfiguración del nosotros-ellos. Paradójico porque Cristiano Ronaldo pasa de un día para otro de ser el "nosotros" a ser el "ellos", no para el ámbito periodístico deportivo de Barcelona (que ya lo era), sino, y esto es lo singular, para el de Madrid: "Cristiano prepárate" y "Mucho ojo Cristiano" (Marca, 26/06/2010 y 29/06/2010), o la declaración en portada de su compañero de club Sergio Ramos "No te hagas ilusiones tú, maquina (refiriéndose a Cristiano Ronaldo)" (As, 27/06/2010). Ambos ejes, Madrid y Barcelona convergen puntual y notablemente en la identificación de un antagonista común en el marco de la identidad como tarea y como proceso.

Un tercer ejemplo en esta línea lo encontramos en el proceso de cierre identitario que Marca y As llevan a cabo, por un lado, y de relectura identitaria que realizan $E l$ Mundo Deportivo y Sport, por otro, a medida que se presume un éxito deportivo sin precedentes por parte de la selección española en el mundial sudafricano. Una vez que se ha dejado atrás el puntual enemigo común portugués encarnado en la persona de Cristiano Ronaldo, se retoma la disputa por contar la identidad en uno u otro sentido. Desde Madrid se intensifican las afirmaciones, los símbolos y los valores que encarnan que España es una y es de todos los españoles. Desde Barcelona se intentan capitalizar las victorias deportivas y los elogios recibidos a nivel mundial por parte de la selección española, mediante una lectura de la misma en términos que resalten, sobre todo, los elementos particulares asociados al FCB y, por extensión, a Cataluña.

A principios del mes de junio de 2010 se estima ya una posible victoria de la selección española en el Mundial. Aunque en el deporte en general las predicciones no siempre resultan del todo acordes con los resultados finales, -al margen de las predicciones del fenómeno mediático pulpo $\mathrm{Paul}^{25}$, con espacios reservados en portada como vemos en la Tabla 1- la mayoría de los expertos en la materia (analis-

\footnotetext{
${ }^{25} \mathrm{Si}$ aún no conoces al pulpo Paul, ver http://es.wikipedia.org/wiki/Pulpo_Paul
} 
tas futbolísticos, prensa especializada, cotizaciones de las casas de apuestas) veían grandes posibilidades de que se produjese un triunfo de España ${ }^{26}$.

Parte del favoritismo que se le da a la selección española tiene que ver con el ya comentado brillante desempeño de los jugadores del FCB que lleva a que se extienda mayoritariamente entre medios y aficionados la idea de que el "estilo de juego" del FCB se ha trasladado a la selección. Está cristalizando un discurso en torno al "barcelonismo" imperante en la selección española. Tal discurso reactiva la cuestión en torno a la identidad contada tanto en el frente periodístico deportivo madrileño, como en el catalán, e incluso más allá, pasando esta cuestión a ser tema de debate entre la opinión pública e incluso se trata de un asunto comentado entre algunos jugadores de la propia selección ${ }^{27}$.

La reacción por parte de Marca y As fue intensificar en sus portadas el lenguaje emotivo, los valores y los símbolos concernientes a la unidad de España, de la selección y, por inferencia, también de la nación española: "España creemos en ti" (25/06/2010); "Esta es mi España" (Marca, 30/06/2010), "Es la hora de España" $(A s, 2 / 07 / 2010)$; declaraciones del seleccionador español Vicente Del Bosque: "El mundial es de todos. No hay una España de Luis (Aragonés, anterior seleccionador) y una España de Del Bosque, sólo hay una España" (As, 10/07/2010).

Este refuerzo y cierre de la identidad española en torno a unos términos unívocos e inequívocos encuentra un buen soporte cuando la prensa deportiva editada en Madrid involucra en sus portadas a la afición española para alcanzar la victoria. En el contexto de los aficionados (el pueblo) funciona de manera eficiente el nacionalismo banal. Si todos estamos con la Roja ${ }^{28}$, todos estamos con España: "46.745.807 corazonadas" y un corazón que se sale de un pecho masculino enfundado en la camiseta roja de la selección española (Marca, 16/06/2010), "¡Toreros!" (As, 30/06/2010); "Podemos (todos) hacer historia (As, 3/07/2010)"; "La final la jugaremos 46 millones" (Marca, 10/07/2010); "Hoy le ponemos una estrella a

\footnotetext{
${ }^{26}$ De hecho la mayoría de casas de apuestas ya veían a España como la gran favorita antes de empezar el Mundial 2010 (cuota media de 5 a 1; la segunda favorita, Brasil se cotizaba 6 a 1). Estas estimaciones se fundamentaban no sólo en el hecho de que la selección española había sido campeona de la Eurocopa 2008, sino también en el brillante juego desplegado por los de Del Bosque y en los resultados alcanzados en la fase de clasificación, donde España ganó todos los partidos.

27 En una entrevista en el portal que patrocina la Liga española (http://www.ligabbva.com/), el jugador de la selección española Fernando Llorente, tras ganar el Mundial 2010, señalaba que el estilo de juego de la selección española y el del FCB es muy similar, sólo que sin Messi. Ver entrevista en

http://www.youtube.com/watch?feature=player_embedded\&v=h-57aCpD9qk\#t=77s

${ }^{28} \mathrm{La}$ Roja es el sobrenombre que se le da a la selección española de fútbol. Resulta significativo como durante el período mundialista el diario Marca ponía junto al logo del periódico el lema: "Todos a una con la Roja". Para mayor profundidad en el tema, ver Sanz (2012).
} 
nuestra camiseta" (Marca, 11/07/2010); "Los campeones del pueblo" (Marca, $13 / 07 / 2010)^{29}$.

Mientras desde Madrid se resalta la unidad, desde Barcelona se incide en la particularidad del éxito que se está cosechando. A diferencia del mundial sudafricano, en el Mundial de Alemania 2006, donde había más jugadores en la selección española del RMCF que del FCB (4 a 3), y al no haber habido éxito deportivo, no había nada que rentabilizar o reclamar en términos de identidad particular. Sin embargo, conforme se va prestigiando el juego de la selección y se van obteniendo resultados positivos en Sudáfrica 2010 se inicia un proceso de relectura y reconfiguración de la identidad por parte de El Mundo Deportivo y Sport para capitalizar el éxito del combinado español, aún a pesar de manifestar al inicio de la competición mundialista un significativo desapego hacia él, salvo en lo que respecta al seguimiento de los jugadores del FCB seleccionados.

Algunos titulares e imágenes de la prensa deportiva editada en Barcelona son muy significativos al respecto de la cuestión de la capitalización de la identidad en interés propio: “¡No pares Villa!” (Sport, 07/08/2010), “¡Puyolazo!” y “¡Puyolazo y a la final!" (Sport, 8/07/2010) y El Mundo Deportivo 8/07/2010, respectivamente), "Barçaspaña" (09/07/2010); "La Roja es blaugrana" y fotografía a portada completa con un fotomontaje donde en la formación de la selección española aparecen siete jugadores del FCB con la camiseta de su club y no con la de la selección española (Sport, 9/07/2010).

En definitiva, desde Madrid se titula en portada el día de la final "España confía en vosotros" acompañado de una foto con los once jugadores de la selección ( $A s$, 11/07/2010), y al día siguiente de la victoria aparece en la fotografía de portada, tanto en Marca como en $A s$, Iker Casillas (RMCF), como capitán de la selección, levantando el trofeo de campeón junto al resto de seleccionados; desde Barcelona se titula en la previa a la final "Quieren esta Copa" (Sport, 11/07/2010) junto a la fotografía de Puyol, Iniesta y Xavi (FCB) y, tras ganar el Mundial, El Mundo Deportivo y Sport individualizan en la fotografía de portada a Iniesta (autor del gol de la victoria) levantando la copa en primer plano sin otra compañía.

\section{Recapitulando}

El objetivo de este artículo ha sido mostrar la potencialidad que tiene analizar los discursos de la prensa deportiva como procesos en los que la presentación y construcción de la identidad nacional se presenta de manera descarnada al albur de los resultados deportivos. Para ello hemos estudiado el caso concreto de la participación de la selección española en el Mundial de Sudáfrica de 2010, que ha constitui-

${ }^{29}$ ¿No recuerda este titular a cuando bautizaron mediáticamente a Belén Esteban, personaje habitual en los programas de periodismo de corazón, como "La Princesa del Pueblo"? 
do hasta el momento el mayor logro deportivo jamás alcanzado por el combinado que representa a España en competiciones internacionales.

Examinamos este proceso a partir de dos polos opuestos en lo deportivo, con seguimientos mediáticos y derivaciones políticas de distinto signo, circunstancia que nos permite ver de manera más meridiana las contradicciones y paradojas que encierra la cuestión identitaria asociada al fenómeno futbolístico. Instrumentalización de jugadores de otras selecciones nacionales al servicio de la identidad propia, volubilidad paradójica en la demarcación de las fronteras nosotros-ellos, y refuerzo (unidad) o reivindicación de una identidad diferencial en función de la coyuntura (en este caso, deportiva de éxito o fracaso) son tres situaciones, que como hemos visto, ejemplifican claramente como los medios de comunicación nos cuentan la identidad, construyéndola y reconstruyéndola a imagen y semejanza de la idea que los propios medios tienen sobre ella.

Estos contrasentidos identitarios aluden principalmente a significados culturales, simbólicos y emocionales que tienen que ver con la presentación y construcción de identidades difusas, más que con planteamientos políticos elaborados, sean de uno u otro signo. La superficialidad desde la que se cuenta y construye la identidad en los medios, especialmente en los diarios deportivos, no resulta asunto baladí, como tampoco lo es el hecho de que este proceso se origine en un escenario futbolístico y mediático. La importancia del fútbol como hecho social total contribuye a descifrar algunos fenómenos a él vinculados, como la cuestión de la identidad nacional. Pero también se abren nuevos interrogantes. En un contexto caracterizado por las tensiones entre lo local y lo global, los debates en torno a la identidad nacional permanecen abiertos, en un mundo donde el incremento de los flujos informativos contribuye activamente a la (re)creación de las cuestiones identitarias individuales y colectivas. La repercusión del fútbol en la sociedad debería llevarnos a pensar si el efecto de los discursos del periodismo deportivo en torno a la identidad nacional no tiene más fuerza socializadora que la de los discursos políticos difundidos por los medios generalistas o diseñados cuidadosamente por otros agentes de socialización implícitos como los partidos políticos. 


\section{Bibliografía}

Adán, Teresa. 1996. Ultras y Skinheads: la juventud visible. Imágenes, estilos y conflictos de las subculturas juveniles en España. Oviedo: Nobel.

Anglés, J. y José M. Gay de Liébana. 2011. "Informe. La Liga apaga el televisor", Don Balón, 1866: 24-27.

Ball, Phil. 2010. Morbo. La historia del fútbol español. Madrid: T \& B editores.

Bauman, Zygmunt. 2006. Vida líquida. Madrid: Paidós.

Bauman, Zygmunt. 2007. Identidad. Buenos Aires: Losada,

Billig, Michael. 1995. Banal Nationalism. London Sage Publications.

Billig, Michael y Rosamaría Nuñez. 1998. "El nacionalismo banal y la reproducción de la identidad nacional", Revista Mexicana de Sociología, 60 (1): 37-57.

Bonaut, Joseba. 2004. "Televisión y deporte en España (1956-1989): una perspectiva cultural", en N. Mínguez y N. Villagra eds., La comunicación. Nuevos discursos y perspectivas. Actas del $7^{\circ}$ Ciclo de Otoño de Comunicación de la Universidad Complutense de Madrid. Madrid: Edipo.

Boniface, Pascal. 2006. "El fútbol, fenómeno global por excelencia”, Dossier La Vanguardia 'El Poder del Fútbol', 20: 6-14.

Brohm, Jean-M. 1982. Sociología política del deporte. México: Fondo de Cultura Económica.

Brohm, Jean-M. .1993. "13 tesis sobre el cuerpo", en José I. Barbero, ed., Materiales de sociología del deporte. Madrid: La Piqueta.

Calvo, E. R., F. Presas y J. Urrutia -Gabinete Caligari-. 1986. "La canción del pollino", Al calor del amor en un bar [CD]. Madrid: Dro/Tres Cipreses.

Cancio, Miguel. 1990. Sociología de la violencia en el fútbol. Santiago de Compostela: Secretaría Xeral para o Deporte, Xunta de Galicia.

Colomé, Gabriel. 1999. "Conflictos e identidades en Cataluña", en Santiago Segurola, ed., Fútbol y pasiones políticas. Madrid: Debate.

Corcuff, Philippe. 1998. Las nuevas sociologías. Madrid: Alianza.

De Miguel, Jesús. 2003. "El ojo sociológico", Revista Española de Investigaciones Sociológicas, 101: 49-88.

Dunning, Eric. 2003. El fenómeno deportivo. Barcelona: Paidotribo.

Durán, Javier. 1996. El vandalismo en el fútbol. Madrid: Gymnos.

Eiré, Alfonso. 1998. O fútbol na sociedade galega. Vigo: A Nosa Terra.

Elias, Norbert. 1992. "La génesis del deporte como problema sociológico", en Norbert Elias y Eric Dunning, Deporte y ocio en el proceso de la civilización. México: Fondo de Cultura Económica.

Elias, Norbert. 2002. Compromiso y distanciamiento. Barcelona: Península.

FIFA. 2009. Los intelectuales del fútbol. Disponible en web: http://es.fifa.com/worldfootball/news/newsid=1092983.html [Consulta: 2 de noviembre de 2012].

Finestres, Jordi. 2007. Barça, més que un club. Barcelona: Angle. 
García Ferrando, Manuel y Francisco Lagardera. 1998. "La perspectiva sociológica en el deporte", en Manuel García Ferrando, Núria Puig y Fransciso Lagardera, comps., Sociología del deporte. Madrid: Alianza.

Giulianotti, Richard. 1997. "Los estudios sociales y culturales del deporte en Europa", Lecturas: Educación Física y Deporte, Buenos Aires. Disponible en web: http://www.efdeportes.com/efd6/rge1.htm [Consulta: 3 de septiembre de 2012].

Gómez, Luis. 2010. "La patria es una camiseta", El País, 9 de julio. Disponible en web: http://elpais.com/diario/2010/07/09/sociedad/1278626401_850215.html [Consulta: 5 de noviembre de 2012].

González Aja, Teresa, ed. 2002. Sport y autoritarismos. La utilización del deporte por el comunismo y el fascismo. Madrid: Alianza.

González Blasco, I. 2008. "Fútbol, fábrica de patriotas", Revista La Clave, 379: 4951.

González Calleja, Eduardo. 2004. "Deporte y poder: El caso del Real Madrid C. de F.", Memoria y civilización, 7: 79-127.

González Ramallal, Manuel E. 2004a. "El reflejo del deporte en los medios de comunicación en España", Revista Española de Sociología, 4: 271-280.

González Ramallal, Manuel E. 2004b. Sociedad y deporte: análisis del deporte en la sociedad y su reflejo en los medios de comunicación. González Radío, Vicente (dir.), Universidade $\mathrm{Da}$ Coruña, A Coruña. Disponible en web: http://ruc.udc.es/dspace/handle/2183/806 [Consulta: 17 de octubre de 2013].

González Ramallal, Manuel E. 2008. "La identidad contada: la información deportiva en torno a la selección española de fútbol", Universitas Humanística, 66: 219-238.

Guibernau, Montserrat. 1996. Los nacionalismos. Barcelona. Ariel.

Hargreaves, John. 1982. "Sport and hegemony: some theoretical problems", en Hart Cantelon y Richard Gruneau, eds., Sport, culture and the modern state. Toronto: University of Toronto Press.

Hargreaves, John. 1986. Sport, power and culture. Cambridge: Polity Press.

Huizinga, Johan. 1987. Homo ludens. Madrid: Alianza. (Trabajo original publicado en 1938).

Laguillaumie, Pierre. 1978. "Para una crítica fundamental del deporte", PartisansVV. AA., Deporte, cultura y represión. Barcelona: Gustavo Gili.

Llonch, Angels. 1996. "Las emociones deportivas en un contexto socio-histórico", en Ricardo Sánchez, ed., La actividad física y el deporte en un contexto democrático (1976 - 1996). Pamplona: Asociación Española de Investigación Social Aplicada al Deporte.

Llopis, Ramón. 2006. "Clubes y selecciones nacionales de fútbol. La dimensión etnoterritorial del fútbol español”, Revista Internacional de Sociología, 45: 37-66.

Llopis, Ramón. 2009. "Sociedad plural, fútbol postnacional. Evolución y transformaciones socioculturales del fútbol español", en Ramón Llopis, ed., Fútbol postnacional. Barcelona: Anthropos. 
Lüschen, Gunter y Kurt Weis. 1979. "Deporte en la sociedad. Posición y cometidos de una sociología del deporte", en Gunter Lüschen y Kurt Weis, comps., Sociología del deporte. Valladolid: Miñón.

Manrique, Juan C. 2011. "Juventud, deporte y falangismo. El Frente de Juventudes, la Sección Femenina y los deportes del 'Movimiento", en Xavier Pujadas, coord., Atletas y ciudadanos. Historia social del deporte en España 1870-2010. Madrid: Alianza.

Marrone, Jesus M. 2009. La importancia de las portadas en las ventas del diario Marca. Paniagua Santamaría, Pedro (dir.). Universidad Complutense de Madrid, Madrid. Disponible en web: http://es.scribd.com/doc/25897413/TESIS-JesusMarrone-La-importancia-de-la-portada-en-las-ventas-del-diario-Marca [Consulta: 24 de octubre de 2012].

Marsh, Peter. 1978. Aggro: Illusion of Violence. London: Dent \& Sons.

Marsh, Peter. 1982. "El orden social en las tribunas de los estadios de fútbol británicos", Revista internacional de Ciencias Sociales, XXXIV (2): 279-288.

Martín Criado, Enrique. 1991. "Del sentido como producción: elementos para un análisis sociológico del discurso", en Margarita Latiesa, ed., El pluralismo metodológico en la investigación social: ensayos típicos. Granada: Universidad de Granada.

Suárez, Orfeo. 2000. Los cuerpos del poder. Barcelona: Casiopea.

Palencia, Manel. 2011. "España-Catalunya. Cambio de liderazgo". Disponible en web: http://www.manelpalencia.com/2011/10/12/espana-catalunya-cambio-deliderazgos/ [Consulta: 9 de enero de 2013].

Pantoja, Antonio. 2007. "La imagen como escritura. El discurso visual para la historia", Revista de Historia, 20: 185-208.

Poli, Raffaele. 2006. "Identidades nacionales y globalización”, Dossier La Vanguardia 'El Poder del Fútbol', 20: 47-50.

Pujadas, Xavier. 2011. "Del barrio al estadio. Deporte, mujeres y clases populares en la Segunda República", en Xavier Pujadas, coord., Atletas y ciudadanos. Historia social del deporte en España 1870-2010. Madrid: Alianza.

Quiroga, Aleiandro. 2013. "El deporte”, en Javier Moreno y Xosé M. Núñez, eds., en Ser españoles. Imaginarios nacionalistas en el siglo XX. Barcelona: RBA.

Relaño, Alfredo. 2010. 366 historias del fútbol mundial. Madrid: Planeta.

Relaño, Alfredo. 2012. Nacidos para incordiarse. Un siglo de agravios entre el Madrid y el Barça. Madrid: Martínez Roca.

Rigauer, Bero. 1981. Sport and Work. Nueva York: Columbia University Press.

Ruíz, Jorge. 2009. "Análisis sociológico del discurso: métodos y lógicas", Forum: Qualitative Social Research, 10 (2): Art. 26. Disponible en web: http:/www.qualitative-research.net/index.php/fqs/article/view/1298/2883 [Consulta: 13 de octubre de 2012].

Santacana, Carles. 2006. El Barça y el franquismo: crónica de unos años decisivos para Cataluña. Madrid: Apóstrofe. 
Santander, Carlos F. 1990. El fútbol durante la guerra civil y el franquismo. Madrid: San Martín.

Santander, Carlos F. 1997. "El Real Madrid ¿fue el equipo franquista?", en Carlos F. Santander, A bote pronto. Madrid: Temas de Hoy.

Sanz, Julián. 2012. "De la azul a "la roja". Fútbol e identidad nacional española durante la dictadura franquista y la democracia", en Ismael Saz y Ferrán Archilés, eds., La nación de los españoles. Discursos y prácticas del nacionalismo español en la época contemporánea. Valencia: Universitat de València.

Shaw, Duncan. 1987. Fútbol y franquismo. Madrid: Alianza.

Taylor, Ian. 1971. "Football Mad: A Speculative Sociology of Soccer Hooliganism", en Eric Dunning, ed., The Sociology of Sport: a selection of Readings. London: Cass.

Villegas, Antonio. 2008. "Explicación del poder de la FIFA sobre los gobiernos". Derecho deportivo en línea, 10: 7-23.

Williams, John. 2009. "¿Clubes frente a selecciones nacionales? Nuevas identidades nacionales y fútbol profesional en Inglaterra”, en Ramón Llopis, ed., Fútbol postnacional. Barcelona: Anthropos. 